WIESŁAW BĄKOWSKI, OSTROŁĘKA NAD PILICĄ

\title{
OSOBOWOŚĆ KATECHETY NA PODSTAWIE WSKAZAŃ KS. MIECZYS ŁAWA WĘGLEWICZA W ŚWIETLE KATECHETYKI WSPÓŁCZESNEJ
}

Owocna posługa katechetyczna to wspólne dzieło katechety, katechizowanych oraz środowiska, w którym katecheza się rozwija. Szczególnie ważna rola przypada tu osobie katechety i jego przymiotom osobowym. Dlatego zasadniczym celem niniejszego artykułu jest próba ukazania modelu osobowościowego katechety działającego wśród młodzieży według wskazań ks. Mieczysława Węglewicza w świetle katechetyki współczesnej. Ksiądz Węglewicz był wybitnym pedagogiem i duszpasterzem młodzieży Archidiecezji Warszawskiej. Jako prefekt nauczał religii w gimnazjum Wojciecha Górskiego w latach 1917-1939. ${ }^{1}$ Reaktywował Koło Księży Prefektów, ${ }^{2}$ ponadto zajmował się redakcją „Miesięcznika Katechetycznego”. ${ }^{3}$

Zawarte w niniejszym artykule treści mogą przyczynić się do zarysowania optymalnego „wzoru katechety”, a poznanie go przez nauczycieli religii pozwoli skuteczniej przekazywać prawdy Boże.

\section{Osobowość w ujęciu katechetyki współczesnej}

Konieczna jest analiza porównawcza zasad głoszonych przez ks. Węglewicza z wytycznymi współczesnej katechetyki, aby na tej podstawie ukazać jego wkład w tej dziedzinie.

1 Por. J. D a j c z a k, Ks. Mieczysław Węlewicz jako pedagog religijny Archidiecezji Warszawskiej, Warszawa 1957, s. 583.

2 Jego działalność przypada na lata 1918-1939; por. E. M a j c h e r, Działalność katechetyczna Ośrodka Warszawskiego w latach 1918-1939 na tle ówczesnego ruchu katechetycznego, Warszawa 1976, s. 82.

3 Tamże, s. 81. 
Pedentologia, czyli nauka o nauczycielu, powstała w Polsce w dwudziestoleciu międzywojennym. Przedwojenna pedentologia charakteryzowała się nachyleniem teoretycznym. Zastanawiano się głównie nad idealnym nauczycielem, nad psychologią, ideologią i filozofią pracy nauczycielskiej, a mniej nad socjologią tego zawodu. ${ }^{4}$ Pedentologia stawiała zawód nauczyciela na równi z kapłanem i lekarzem, podnosząc do go rangi posłannictwa i powołania. ${ }^{5}$

Obecnie pedentologia zwraca uwagę na nauczyciela jako jednostkę, która wpływa decydująco na efekty nauczania i wychowania. Zarówno dawniej jak i dziś w pedentologii podkreśla się charakter twórczy zawodu nauczycielskiego. Współcześnie w wymaganiach twórczej inicjatywy nauczyciela zalecany jest umiar i pragmatyczna trzeźwość. Utożsamianie autorytetu pedagogicznego z twórczością pedagogiczną nauczycieli i wychowawców w warunkach współczesnego życia szkoły jest przydatne, lecz wbrew oczekiwaniom i dobrym intencjom pedentologów nie musi sprzyjać postępowi pedagogicznemu, a może nawet stanowić zaporę w doskonaleniu pracy nauczycielskiej na co dzień. Pedentologię interesują cechy osobowości nauczyciela, które decydują o jego skutecznym wpływie na ucznia. Dokonuje także analizy czynników decydujących o pojawieniu się danych cech. ${ }^{6}$

\section{Cechy pedagogiczne osobowości katechetycznej}

Do cech pedagogicznych osobowości katechety należą cechy: charakteru, religijności, autorytetu, pokory, miłości pedagogicznej, taktu, radości, intuicji, obserwacji, twórczości, pomysłowości praktycznej, postawy społecznej, powołania wewnętrznego.

4 Por. J. Ta r now s k i (red.), Zadania współczesnego wychowawcy, Collectanea Theologica 3/1970, s. 158.

5 Ustawiała go na czołowym miejscu w hierarchii prestiżu zawodowego, zaliczając do zawodów z kręgu ,inżynierii dusz ludzkich”. Domagała się od wychowawcy mistrzostwa pedagogicznego, które z reguły utożsamiała z ,intuicją” bądź „twórczością pedagogiczną”, analogiczną do twórczości artystycznej; por. tamże.

6 Por. W. K u b i k, Problem nauczyciela, Collectanea Theologica 3/1969, s. 167. 


\section{Cecha charakteru}

Do cech pedagogicznych osobowości katechetycznej należy przede wszystkim cecha charakteru chrześcijańskiego. ${ }^{7}$ Problem charakteru jest dziś szeroko omawiany we wszystkich gałęziach wiedzy humanistycznej, której przedmiotem głównym jest człowiek wraz z wrodzoną i nabytą osobowością. ${ }^{8}$ Charakter chrześcijański kształtuje się na podstawie dyspozycji nadprzyrodzonych, które są zaszczepione w duszy razem z łaską uświęcającą przez sakrament chrztu. Punktem wyjścia w pracy nad kształceniem chrześcijańskiego charakteru jest, według bp. Bilczewskiego, „unadnaturalnienie przez okulizację natury człowieka łaską uświęcającą, która jest wyższą, jakby Bożą duszą naszej duszy". 9

Wzorem doskonałego chrześcijanina jest upodobnienie się do „obrazu Syna Bożego” (Rz 8, 29). Z tego wynika postulat wyższej sprawiedliwości, wyższej miłości Boga i miłości bliźniego oraz służby dla drugich: „Kto by między wami chciał być pierwszym, niech będzie ostatnim ze sług waszych" (Mt 20,27). Cechą charakteru chrześcijańskiego jest również nieustanne przezwyciężenie siebie, połączone $\mathrm{z}$ nieustannym trudem, ofiarą i niekiedy męczeństwem, ${ }^{10}$ gdyż ,jeśli kto chce iść za Mną, niech zaprze się samego siebie, weźmie krzyż swój na każdy dzień i niech Mnie naśladuje" (Łk 9,23).

7 J. D a j c z a k, Katechetyka, Warszawa 1956, s. 319.

8 J. Daj czak, F. Wor on ow ski, O. Nas s a 1 s ki, J. Tarnowski, J. P a s t u s z k a, Rozważania duszpastersko-katechetyczne, Poznań 1967, s. 25. W najszerszym tego słowa znaczeniu przez charakter rozumie się pewien zespół cech indywidualnych przysługujących ludziom, zwierzętom, roślinom czy innym rzeczom, którymi zarówno ludzie, jak i byty pod-osobowe w swych poszczególnych jednostkach między sobą się wyróżniają tak dalece, że każdy z tych bytów jest w pewnym stopniu oryginalny i jako taki nie powtarza się w drugich bytach; por. tamże. Charakter w węższym znaczeniu wyraża stanowczość, siłę, trwałość w dążeniu woli do pewnego celu, a także wartościowaną dążność pod względem moralnym do określonego celu. Nazwa „charakter” pochodzi od greckiego słowa charassein - „ostrzyć”, „karbować”. Por. tamże, 26.

9 J. D a j c z a k, Katechetyka, s. 321-322.

10 Por. tamże, s. 322. 
Mimo jednak wszelkich, nawet najcięższych cierpień, chrześcijanin odznacza się niewyczerpaną radością i pogodą ducha, płynącą ze źródeł przyrodzonych i nadprzyrodzonych, po myśli zaleceń Kazania Chrystusa na Górze i nauki św. Pawła zawartej w Liście do Filipian: „Weselcie się zawsze w Panu, powtarzam: weselcie się" (Flp 4,5).

Chrześcijanin, złączony powszechną więzią braterstwa w Mistycznym Ciele Chrystusa, spełnia wolę Bożą z miłości ku Niemu. Według św. Pawła, człowiekiem i osobowością katechetyczną nie mającą charakteru chrześcijańskiego jest ten, kto nie zachowuje przykazania miłości. Człowiek taki nie spełni swych zadań, choćby miał pewne cechy pedagogiczne i dydaktyczne. „Gdybym mówił językami ludzi i aniołów, a miłości bym nie miał, byłbym jak miedź brzęcząca, albo cymbał brzmiący" (1Kor 13,1). Katecheta powinien być nacechowany entuzjazmem, działaniem, walką. ${ }^{11}$

\section{Cecha religijności}

Postawa religijna charakteru nauczyciela-katechety skłania go do optymistycznego spojrzenia na świat i życie, zmusza go do głębszej refleksji, do przestrzegania pewnego programu i zdobywania

11 Por. L. K a c z m a r e k, Postawy życiowe katechety, Katecheta 2/1978, s. 242. Nie można wyznawać haseł takich, jak: „Niech się dzieje co chce na świecie, byle bym ja miał spokój”. „Nikomu nic złego nie czynię, mam sumienie spokojne, najlepiej nie mieszać się w sprawy cudze”. „Pragnę ciszy i spokoju”. Tego rodzaju hasła nie pokrywają się z programem życia chrześcijańskiego. Walka w życiu katechety, podobnie jak walka w życiu w ogóle, dokonuje się na dwóch frontach. Przede wszystkim walka wewnętrzna bez względu na to, czy się jest chrześcijaninem, buddystą czy ateistą. Człowiek odczuwa w sobie nagromadzenie instynktów dążności, pragnień, może nie złych samych w sobie, ale które trzeba trzymać w ryzach i poświęceniu dla dobra całości. A to wymaga walki w każdej chwili. Opanowanie swoich skłonności jest warunkiem postępu w życiu chrześcijańskim i tego samego powinien uczyć katecheta, sam służąc przykładem. Nie może być osobą bezduszną, wygodną, bierną, pasywną. Przeciwnie, Nie może być wyznawcą i rzecznikiem bezdusznej znieczulicy, z jaką dziś spotykamy się niejednokrotnie na co dzień; por. tamże, s. 323. 
umiejętności przewidywania. ${ }^{12} \mathrm{Z}$ religijnej postawy nauczyciela-wychowawcy wyrasta duch apostolstwa względem młodzieży. Każdy nauczyciel, szczególnie katecheta, jest w duchu apostołem, duszpasterzem. W procesie nauczania uczniowie powinni poznać i doświadczyć, że jest im dobrze z nauczycielem-katechetą, bo pod jego przewodnictwem staną się wartościowsi, szlachetniejsi i mądrzejsi. Katecheza powinna być dla dzieci szkolnych ćwiczeniem w pobożności: „Przez wiarę dzieci przyjmują za prawdę to, co Bóg objawił i przez Kościół Katolicki do wierzenia podaje. (...) W słowach katechety dzieci słyszą echo słowa Bożego, zwiastującego im radosną nowinę zbawienia". ${ }^{13} \mathrm{Z}$ przewodnictwa duchowego katechety wyłania się wyczucie dobra i zła. Tylko religijny człowiek odczuwa religijność bliźniego i pragnie odzwierciedlenia tych cech u swoich bliskich. Katecheta ma więc obowiązek moralny upominania młodzieży, gdy ona błądzi.

Jakie wymagania stawia dziś Kościół swoim kapłanom ${ }^{14}$ uczącym dzieci i młodzież? Domaga się, aby kapłan był naprawdę wierzącym kapłanem i chrześcijaninem. ${ }^{15}$ Kapłan obecnie ma być zdyscyplinowany i posłuszny swej władzy. Współczesny kapłan musi być rozmodlony, gdyż specyficznych niebezpieczeństw światowych nie opanujemy inaczej, jak tylko starą receptą Chrystusa: modlitwą i postem. Ponadto kapłan musi być nowoczesny. Kościół zachęca bezustannie do szukania nowych dróg i nowych metod, do wykorzystywania wszystkich nowoczesnych wynalazków w duszpasterstwie i katechezie. ${ }^{16}$

12 Por. tamíe.

13 U dzieci należy wzbudzić przekonanie, że nauka, którą słyszą z ust katechety, jest nauką Kościoła, a to, czego uczy Kościół, pochodzi od Boga; por. tamże.

14 Por. B. K o m i n e k, Typ współczesnego katechety, Katecheta 1/1960, s. 9-11.

15 To nie jest ani żart, ani banalne powiedzenie; niejeden bowiem kapłan-katecheta żyje i postępuje tak, jakby nie wierzył w to, czego uczy młodych. W ten sposób nie tylko osłabia, lecz nawet przekreśla swym zachowaniem to, czego uczy, a ponadto jest strasznym i tragicznym gorszycielem młodzieży; por. tamże.

${ }_{16} \mathrm{Z}$ punktu widzenia Kościoła problem dzisiejszego kapłana polega właśnie na umiejętności pogodzenia dobrego ducha kapłańskiego i dobrego stylu życia 


\section{Cecha autorytetu}

Cecha autorytetu oznacza ${ }^{17}$ że w procesie nauczania katecheta wprowadza wychowanków w krąg swych poglądów, przekonań, sądów i dążeń, aby przez niego patrzyli na świat i życie. W środowisku kościelnym i szkolnym katecheta jest zastępcą Chrystusa ${ }^{18}$ mocą misji kanonicznej udzielonej mu przez biskupa diecezji. Świadomie pełni w imieniu Kościoła misję ewangeliczną i jest świadkiem Chrystusa. Do katechety pośrednio odnoszą się słowa Jezusa: „Jak mnie posłał Ojciec, tak i Ja was posyłam" (J 20,21). Katecheta użycza Bogu swych ust mówił św. Jan de La Salle. To nakłada na katechetę obowiązek życia zgodnego ze swym powołaniem, by był rzetelnym narzędziem łaski. ${ }^{19}$

Święty Jan XXIII 13 lutego 1961 r. w przemówieniu do kaznodziei Rzymu powiedział: „Powtarzać słowo objawione i odważać się komentować je, stosować je doktrynalnie, to sprawa obciążająca sumienie i dlatego wymaga się, by kapłan był do tego uprzednio przygotowany, aby był narzędziem uległym, aby mógł spełniać swoje wzniosłe zadanie w imieniu całego Kościoła". ${ }^{20}$ Zdaniem P. Poręby, zapotrzebowanie na autorytet osobowościowy wśród młodzieży wynika z sytuacji psychicznej okresu młodzieńczego. ${ }^{21}$ Jeżeli ma być

kapłańskiego z nowoczesnością metod duszpasterskich i szukania nowych dróg podejścia do młodego pokolenia; por. tamże, s. 11.

17 Słowo ,autorytet” pochodzi pod względem etymologicznym od wyrazów łacińskich augere (,pomnażać”) i auctor (,sprawca”). W tym ujęciu oznacza zdolność dawania i pomnażania życia; por. J. D a j c z a k, Katechetyka, s. 324.

18 Por. Katecheta, 1934, s. 78-79.

19 Tamże, s. 79.

20 Tamże. W dobie demokratyzacji życia, krytycyzmu i uniezależnienia się młodzieży wiele mówi się o zaniku autorytetu utożsamianego ze sprawowanym urzędem. Nie traci natomiast na aktualności autorytet osobowościowy, którego przejawem jest szacunek okazywany człowiekowi dla jego osobistych zasług, oraz dobrowolne liczenie się ze zdaniem człowieka, który dowiódł, że wart jest tego posłuchu; por. S. J a c k o w s k i, Osobowość katechety młodzieży, Chrześcijanin w świecie 56-57/1977, s. 109.

${ }_{21}$ Wniosek ten wygląda na paradoks w zestawieniu z prawdą, że krytycyzm i bunt dojrzewania objawia się m.in. w odrzucaniu autorytetów. To prawda, ale przez 
zaakceptowany przez katechizowanych, autorytet katechety musi opierać się na prawdziwych wartościach osobowych i ponadto przybierać charakter autorytetu wyzwalającego, budzącego w młodych gotowość i umiejętność samodzielnej pracy nad własnym rozwojem. ${ }^{22}$

W miarę rozwoju osobowościowego młodzieży, rola autorytetu jako pomocy i wsparcia winna coraz bardziej przechodzić w zadanie przewodnictwa. Jednocześnie w miarę wzbogacania się wzajemnych oddziaływań autorytet katechety winien być coraz mocniejszy w relacji do całej grupy katechetycznej, stanowiąc dodatkowy element jej wzrostu i umacniania więzi międzyosobowych. ${ }^{23}$ Autorytet wychowawcy jest zawsze konieczny, gdyż bez niego niemożliwe byłoby oddziaływanie na wychowanka. Obecnie jednak niekorzystnie zmienia się typ tego autorytetu, gdyż jest coraz mniej ludzkiej miłości i podziwu, a coraz częściej i więcej szacunku zabarwionego lękiem powodowanym zależnością. ${ }^{24}$

\section{Cecha pokory}

Cechy naturalności, prostoty i szczerości winny być u wychowawcy z powołania zawsze żywe i nienaruszone, mimo doznawanych przez niego zawodów ze strony tych, którym ufał i wierzył. U prawdziwego pedagoga występuje prostota, naturalność i szczerość pod

ten krytycyzm i radykalizm przeziera również idealizm. Na drodze rozwoju swej osobowości młodzi szukają nieraz wsparcia i pomocy, ale jedynie tych, u których dostrzegają zgodność głoszonych zasad i życia; tamże.

22 Chcąc taki stan osiągnąć, katecheta nie może być człowiekiem ,gotowym”, lecz twórczym, umiejącym wciąż na nowo „zapracowywać” na swój autorytet; tamże.

23 Tamże.

24 Por. J. Ta r now s k i (red.), Zadania współczesnego wychowawcy, s. 158. Wysoki prestiż nauczyciela wypływa dziś nie tyle z przewagi kulturalno-intelektualnej, ile z przewagi administracyjno-technicznej, ponieważ w jego ręku leży los dziecka, od niego zależy promocja, przyszłość, opinia. Katecheta winien mieć jednak autorytet moralny, autorytet opiekuna, przyjaciela oraz doradcy w sprawach życiowych. Badania wykazują, że nauczyciele często tej roli nie spełniają; tamże, s. 159. 
postacią skłonności do wierzenia ludziom i liczenia w realizowaniu planów wychowawczych przede wszystkim na pomoc Bożą. Taki był wielki wychowawca dzieci opuszczonych św. Wincenty à Paulo, św. Jan Bosco i inni świeccy wychowawcy. ${ }^{25}$ Podobne cechy prostoty, szczerości i pokory dostrzec można w życiu Makarenki, czołowego pedagoga radzieckiego. ${ }^{26}$

Cechy pokory często nazywane są przez niektórych pedagogów infantylizmem, bezpośredniością, a nawet naiwnością dziecięcą. ${ }^{27}$ Jednakże inni pedagodzy są zdania, że pokora jest niezbędnym warunkiem talentu pedagogicznego, który jest funkcją osobowości pedagogicznej. Nauczycielowi niepokornemu niełatwo przychodzi poznanie psychiki dziecka. ${ }^{28}$

\section{Cecha miłości pedagogicznej}

Cecha ta ${ }^{29}$ wyraża się w skłonności do twórczego obcowania z młodzieżą i doznawania $z$ tego ustawicznej radości ${ }^{30}$ oraz wywierania

25 Por. J. D a j c z a k, Katechetyka, s. 327.

${ }^{26}$ Gdy mu przypadło prowadzić kolonię im. Gorkiego, w której miał wychować młodocianych przestępców, czuł się wobec nich bezradny, nie widząc żadnych sposobów wyjścia z trudnej sytuacji. Intuicyjnie, podświadomie jednak kierował się wiarą w wartość człowieka i z bezgraniczną miłością do młodocianego pokolenia. Był niepoprawnym optymistą i pracę swoją budował na wierze człowieka. Praca jego dała obfite owoce. Ostatecznie zwyciężył i z bezmyślnych włóczęgów wychował uspołecznionych obywateli; por. tamże.

27 Por. tamże, s. 328.

${ }_{28}$ Grzech śmiertelny, który się w nim zakorzenił, utrudnia mu poznanie dziecka. Tym grzechem jest gniew, który występuje razem z pychą. Zatem z punktu widzenia psychologicznego, etycznego i społecznego niezbędna jest cecha pokory w strukturze osobowości katechetycznej i w ogóle pedagogicznej u każdego dobrego nauczyciela; por. tamże.

29 Miłość pedagogiczna jest osobliwą formą miłości społecznej i religijnej; por. tamże.

30 Tamie, s. 330. 
wpływu na duchowy wzrost małoletnich. ${ }^{31}$ Psychiczną podstawę tej cechy stanowi prawdziwa życzliwość niesienia pomocy młodemu człowiekowi w jego pracy nad rozwojem i wzbogaceniem osobowości. Jeszcze ważniejsza jest umiejętność wpływu nie tylko słowami, lecz bezpośrednim oddziaływaniem uśmiechem, spojrzeniem, ciepłym gestem ujawniającym autentyczną życzliwość i zrozumienie. ${ }^{32}$ Miłość wychowawczą określa również idea wspólnoty społecznej, w wyniku której wychowawca poczuwa się wraz z wychowankami do przynależności do jednego narodu, jednego państwa, jednej kultury i jednego Kościoła. Miłość pedagogiczna jest pod względem mistycznym miłością w Chrystusie lub miłością w „duchu i prawdzie”, zgodnie ze starochrześcijańską maksymą etyczną: Vidisti fratrem tuum - vidisti Dominum tuum. ${ }^{33}$

Drugą cechą miłości pedagogicznej jest aktywna postawa nauczyciela pragnącego wzbogacić wychowanka o wszystkie możliwe wartości, którymi tylko rozporządza. Wychowawca otwiera przed uczniem swoją osobowość i zaprasza go do współpracy. Przyjaźń wiążąca nauczyciela z uczniem powinna być dwustronna. ${ }^{34}$ Uczeń nieustannie wzbogaca się w tej wspólnocie i kształtuje na wzór swego wychowawcy. Nowoczesne wychowanie młodzieży przez szkołę domaga się, aby klasa stała się w coraz liczniejszych okazjach „okrągłym stołem”, przy którym się dyskutuje i ocenia, porównuje

31 Nie wystarczą tylko zabiegi i organizacja szkoły, dobór treści programowych, ale istotne są indywidualne wysiłki nauczycieli i troska o osobisty, wychowawczo-intymny związek i bliskość wychowawcy z wychowankiem. Por. J. Ta r n o w s k i (red.), Zadania współczesnego wychowawcy, s. 161.

32 Brak tego przejawu miłości pedagogicznej mógłby być powodem, że młody, uczulony na objawy życzliwości, doznając zawodu, zamknąłby się wewnętrznie na wpływy wychowawcze, a w konsekwencji zahamował w rozwoju wrodzonej uczuciowości; por. S. J a c k o w s k i, Osobowość katechety młodzieży, s. 108.

33 „Widziałeś brata twego, ujrzałeś Pana twego”. Miłość ta nie jest zwykłą eros, przepojoną pewną dozą egoizmu (amor concupiscentias), lecz przyjaźnią (amor benevolentias); por. J. D a j c z a k, Katechetyka, s. 330-331.

34 Por. tamże, s. 331. 
i wybiera, rozważa. ${ }^{35}$ Specyfika polskiego środowiska stawia przed katechetą wymagania jeszcze większej wyrozumiałości i cierpliwości. Postulat ten jest podyktowany faktem istnienia w polskiej sytuacji katechetycznej znacznie większego rozdźwięku między ideałem wychowawczym a ,prozą życia”, niż to wynika z samej natury każdego procesu wzrostu i rozwoju. ${ }^{36}$ Specyficznym przejawem miłości pedagogicznej u katechety jest radość płynąca $\mathrm{z}$ faktu, że można być komuś pomocny na drodze wiodącej do spotkania z Bogiem. Takie ukierunkowanie powołania jest zdolne sprawić, że praca z młodzieżą stanie się pasją życiową katechety. ${ }^{37}$

35 Konieczne jest skończenie z podziałem na „katedrę”, z której się głosi, i „ławki”, w których się słucha. Na katechezach trzeba analizować nie tylko to, co przynosi na dzień dzisiejszy kolejny temat lekcyjny, ale i to, co przynosi film i radio, telewizja i gazety; por. J. Ta r n ow s k i (red.), Zadania współczesnego wychowawcy, s. 161.

36 Ideał ukazywany przez polskiego katechetę często zderza się w świadomości młodych z zupełnie innym ideałem, ujętym programowo i metodycznie, przekazanym przez ludzi nierzadko lubianych i cenionych. Taka sytuacja oczywiście nie pozostaje bez wpływu na proces rozwojowy młodego człowieka, czego katecheta musi być świadomy i odpowiednio nastawić się w pracy; por. tamże.

37 Bez tego nie byłby on zdolny znieść niepowodzeń i braku widocznych owoców, pozornie zmarnowanych wysiłków, często, niestety, nieodłącznych od jego posługi. Z drugiej strony, tak ustawiona miłość pedagogiczna uchroni katechetę przed zbyt łatwymi sympatiami, a także pokusą stawiania jednych ponad drugich, co bardzo rozluźnia więź wychowawczą i wzajemne zrozumienie; por. S. J a c k o w s k i, Osobowość katechety młodzieży, s. 108. Przeciwieństwem miłości pedagogicznej jest nienawiść lub rażąca obojętność wobec uczniów. U nauczyciela może też nastąpić wypaczenie zmysłu wartościowania, w wyniku którego może niesłusznie zaprzeczać wartości uczniowi, albo też żywić w sobie chęć zniszczenia tych wartości, które uczeń ma w sobie. Nie sprzeciwia się miłości pedagogicznej, jeśli się okazuje sympatię bezwartościowej jednostce, aby w niej budzić i pielęgnować wartości. Z drugiej też strony nie wykracza się przeciwko miłości pedagogicznej, jeśli się nienawidzi w pewnym osobniku jego wady i przywary jako zło w nim istniejące, przeciwne wartościom duchowym; por. tamże, s. 332 . 
Cecha taktu w wychowaniu

Formacja psychologiczno-pedagogiczna katechety powinna zmierzać w kierunku wyrobienia w nim taktu pedagogicznego. ${ }^{38}$ Takt wyrażałby się przez właściwą postawę wobec wychowanka, a także przez posłużenie się właściwymi metodami i środkami pedagogicznymi w kontakcie wychowawczym z wychowankiem. ${ }^{39}$

Podstawowym warunkiem kształcenia w sobie taktu pedagogicznego jest, oprócz wrodzonej dyspozycji taktu, głęboka znajomość własnej osobowości, jasnych i ciemnych stron charakteru, rozumienie i wczuwanie się w radości i troski dziecka, poszanowanie jego tworzącej się osobowości pod względem jego ontologicznej godności oraz poznania środków pedagogicznych, którymi powinien dysponować. Ponadto do wymienionych środków samowychowania taktownego nauczyciela należą: idea wyrzeczenia się siebie; poświęcenie się dla dzieci; religijna postawa nauczyciela wobec życia i swego zawodu. ${ }^{40}$ Taktowne postępowanie nauczyciela oddziałuje sugestywnie na uczniów i pobudza ich do naśladowania taktu wychowawcy. ${ }^{41}$

38 Por. M. M aj e w s k i, Przygotowanie psychologiczno-pedagogiczne katechetów, Collectanea Theologica 4/1974, s. 156. W działalności katechetycznej istnieje zapotrzebowanie na katechetów psychologów i katechetów pedagogów, a nie znawców psychologii i pedagogiki. Od katechetów wymaga się, by umieli przenieść i stosować zdobytą wiedzę w swoim środowisku pracy; por. tamże, s. 155.

39 Takt ma w wychowaniu doniosłe znaczenie. I słusznie, gdy nauczyciel za pomocą tego daru nawiązuje przyjazny stosunek z całą klasą, rozumie indywidualnie uczniów. Również pod względem dydaktycznym umie zainteresować uczniów przedmiotem nauki, wywołać w klasie pozytywny nastrój do niej i nawiązać do życia. Nauczyciel taktowny zna także granice pojętności uczniów, ma wyczucie tego, co ważne, a co mniej ważne; por. tamże, s. 156.

40 Por. tamże, s. 337.

41 Taktu nie można się nauczyć. Trzeba już mieć jego zadatki przychodząc na świat. Zwykle dziedziczy się go po matce i innych żeńskich przodkach. Takt wrodzony wynika z wrodzonych dyspozycji, intuicji, sympatii i szacunku dla drugich; por. tamize. 
Cecha radości w wychowaniu

Atmosfera radości nie jest czymś dodatkowym w środowisku szkolnym. Przeciwnie, jest postulatem istotnym i niezbędnym do oddziaływania wychowawczego. Nie chodzi tu o radość jako przejściowe, nastrojowe uczucie, lecz niewyczerpaną sympatię do uczniów. ${ }^{42}$ Do atmosfery radości w szkole wiele wnosi osobowość nauczyciela, odznaczającego się poza wartościami uzdolnień i umiejętności zawodowych duchem optymizmu, zamiłowania do zawodu, bezinteresowną miłością najwyższych wartości, z Bogiem na czele. ${ }^{43}$ Motywy czysto naturalne nie są w mocy utrzymać dyscypliny i twórczej radości w pracy szkolnej. One szybko się zużywają, zanikają w codziennych zmaganiach ze słabością, dokuczliwością i lenistwem młodzieży oraz obojętnością, a nawet wrogością domu rodzinnego wobec szkoły.

Pedagog chrześcijański, który ma cechę poczucia humoru, będzie istotą pogodną, wiecznie młodą. Za żartobliwością kryć się będzie w nim powaga i zdrowy optymizm. Przed pesymizmem i rozpaczą bronić się będzie głęboką wiarą w swe zaszczytne powołanie do zaszczepiania i rozkrzewiania odwiecznych wartości w konkretnych osobowościach ludzkich.

\section{Cecha intuicji}

Cecha intuicji sprawia, że wychowawca znacznie szybciej poznaje uczniów niż za pomocą obserwacji, doświadczenia i rozumowania. ${ }^{44}$ Filozofia katolicka przyjmuje za św. Tomaszem w procesie poznania strukturę czynników współzależnych od siebie, opartą na syntezie zdrowych kierunków filozoficznych. Uznaje zarówno doświadczenie zmysłowe, jak też refleksyjne myślenie. W rozwiązywaniu problemów posługuje się zarówno indukcją, jak i dedukcją. Pewną też rolę

\footnotetext{
42 Por. tamże, s. 338-339.

43 Tamże, s. 339.

44 Por. tamże, s. 340.
} 
przypisuje w poznaniu uczuciom, instynktom oraz intuicji. ${ }^{45}$ Poznanie intuicyjne nie jest obce lub przeciwne inteligencji, gdyż czynności jego należą właściwie do inteligencji.

Umysłowość wychowawcza kobiety przewyższa pod względem wyposażenia w intuicję umysłowość męską. Kobieta, predysponowana w procesie myślenia do rzeczy konkretnych, indywidualnych i życiowych, góruje nad mężczyzną w szybkim poznawaniu ludzi, w odróżnianiu ich charakterów, w śmiałej i wnikliwej diagnozie ich osobowości oraz w bystrej i roztropnej orientacji w najtrudniejszych nawet sytuacjach życiowych. ${ }^{46}$

\section{Cecha obserwacji pedagogicznej}

Duchowy obraz wychowanka, który nauczyciel zdobył dzięki intuicji, musi być poddany rozumowej krytyce stwierdzającej jego obiektywność. Podłożem psychicznym tego rodzaju próby jest zdolność obserwacji pedagogicznej. ${ }^{47}$ Chociaż w wielu zawodach jest ona potrzebna, to w wychowaniu nabiera szczególnego znaczenia. U katechety spostrzegawczość i osąd na niej oparty powinny w stosunku

45 Nie usamodzielnia ich jednak, ani też nie przyznaje im wyłącznej, absolutnej roli w funkcjach sensoryczno-percepcyjnych, lecz twierdzi, że one wszystkie stanowią jeden organiczny, wewnętrzny i współzależny od siebie układ poznawczy, hierarchicznie ugrupowany dookoła jego trzonu, którym są duchowe władze poznawcze; por. tamże.

46 Jednakże irracjonalne poznanie intuicyjne, oparte w wychowaniu na przeczuciach, „oglądzie” zmysłowym, „natchnieniach” i przeżyciach jest pozbawione siły dowodowej. Nie można zbyt pospiesznie opierać na nim swego postępowania, bez potwierdzenia jego prawdziwości na drodze obserwacji pedagogicznej i myślenia opartego na abstrakcji, syntezie i analizie; por. tamże, s. 341.

47 Obserwację dzielimy na zewnętrzną i wewnętrzną. Funkcję pierwszej spełniają zmysły, zwłaszcza wzrok i słuch, z którymi na podstawie wielozmysłowych procesów poznania, współdziała również reszta zmysłów, wyobraźnia usłużna oraz trwała pamięć, jak również inteligencja praktyczna codziennego życia. Obserwacja wewnętrzna refleksyjna powstaje z połączenia i porównywania spostrzeżeń, wyobrażeń, doznań i doświadczeń oraz przeprowadzania ich przez umysł czynny w postaci sądów i wniosków; por. tamże, s. 342-343. 
do uczniów obejmować najdrobniejsze szczegóły ich życia fizycznego, psychicznego i duchowego tworzącej się osobowości, celem określenia jej przynajmniej w zarysach i pokierowania jej rozwojem. Dlatego psychologowie nazywają dyspozycję zmysłu obserwacyjnego wrodzoną zdolnością stawiania diagnozy osobowości. ${ }^{48}$

Pedagog łączy w sobie zdolności do obserwacji zewnętrznej i wewnętrznej. ${ }^{49}$ Nie tylko orientuje się szybko w różnych sytuacjach zewnętrznych, lecz również szybko, logicznie, jasno i praktycznie rozumuje oraz prędko decyduje się w działaniu, według postulatów obserwacji pedagogicznej. Aby móc poznawać ucznia na lekcjach teoretycznych i praktycznych, konieczna jest wiedza o podstawowych motywach postępowania człowieka, prawidłowości rozwoju młodzieży i metodach poznawania ucznia. ${ }^{50}$

\section{Cecha twórczości}

Nie przestaje się dzisiaj zwracać uwagi na zalety woli i charakteru nauczyciela, które powinny przejawiać się w konsekwencji i wytrwałości w pokonywaniu przeszkód, w stałości i prawości charakteru oraz sprawiedliwości, ale głównie akcentuje się znaczenie właściwości intelektualnych nauczyciela. Mówi się o roli poziomu intelektualnego nauczyciela, który zapewni mu skuteczne oddziaływanie w procesie nauczania. Poziom intelektualny nauczyciela powinien przejawiać się w postawie, która pobudzi go do własnej twórczości,

48 Por. tamże, s. 344.

49 Obserwacja pedagogiczna nauczyciela powinna być zarówno dokładna, jak uczonego, i duchowa, jak świętego. Przedmiotem jego obserwacji powinno być potrójne życie uczniów: organiczno-fizjologiczne, psychologiczne i duchowe. Niestety, nauczyciele nie znają często swych uczniów. Wykazuje to dr E. Turska na podstawie analizy „Arkusza ocen ucznia” w jednej ze szkół przyzakładowych. Procent zgodności ocen był bardzo niski (poza oceną stanu fizycznego); średnia dochodziła nawet do $50 \%$; por. tamże.

50 Por. J. Ta r now s k i (red.), Zadania współczesnego wychowawcy, s. 161. 
chociażby w małym zakresie. ${ }^{51}$ Postawa twórcza skłoni nauczyciela do prowadzenia prawdziwej pracy badawczej, a to z kolei wpłynie korzystnie na jego działalność pedagogiczną i stanie się czynnikiem pobudzającym twórczość uczniów. ${ }^{52}$

Mówiąc o metodach pracy nauczyciela, należy stwierdzić, że styl jego pracy zależy przede wszystkim od wiedzy i świadomości. ${ }^{53}$ Czynnikiem regulującym i modyfikującym działanie jest wiedza, posiadana teoria i sposób posługiwania się nią. ${ }^{54}$ Najlepiej pod względem metodycznym pracuje nauczyciel, który stale kieruje się określonym celem akcji, kontroluje jej przebieg oraz wyniki. Przewidując skutki i dostrzegając efekty swojego oddziaływania, łatwo może modyfikować i korygować swoje metody pracy. ${ }^{55}$

\section{Cecha pomysłowości praktycznej}

Cecha ta polega na tym, aby katecheta umiał skutecznie wykorzystać każdą cząstkę posiadanej wiedzy. Cechę tę winna mieć

${ }^{51}$ Kładzie się wielki nacisk na walory intelektualne nauczyciela, na to, by zdobywał on możliwie najbardziej rozległą wiedzę o przyrodzie, społeczeństwie i kulturze, by miał własne wyrobione przekonanie, które może przekazywać innym; por. W. Ku b i k, Problem nauczyciela, s. 168.

52 Celem ustawicznego doskonalenia swej pracy nauczyciel powinien ją kontrolować i odpowiednio modyfikować. Stale powtarzające się schematy działania sprawiają, że nauczyciel szafuje gotową odpowiedzią tam, gdzie sytuacja wychowawcza wymaga głębszego zbadania; tamże, s. 169.

53 Tamże.

54 Nauczyciel, który nie przygotował się należycie przed lekcją, nie zdobył odpowiedniej wiedzy, może być wprawdzie bardzo aktywny w czasie lekcji, ale nie będzie umiał wyzwolić aktywności uczniów. Natomiast nauczyciel, który rozwinął swą aktywność przed lekcją przez odpowiednie rzeczowe przygotowanie się do niej, będzie umiał wyzwolić aktywność uczniów i odpowiednio nią pokieruje. Dopuści uczniów do planowania i ustalania zadań, uwzględni ich inicjatywę, pozwoli im stawiać pytania i poszukiwać własnych rozwiązań; por. tamże.

55 Jest to jednak możliwe wyłącznie przy stałym zdobywaniu i poszerzaniu odpowiedniej wiedzy oraz doświadczenia; por. tamże. 
każda osobowość pedagogiczna. ${ }^{56}$ Wytrawny pedagog jest w sztuce nauczania i wychowania, w sposób oryginalny i wzorowy, bardzo pomysłowy. Punktem wyjścia pomysłowości praktycznej osobowości katechety są u duszpasterza cechy przezorności i roztropności życiowej. Wówczas wybiera on nie tylko najlepsze cele i obmyśla najodpowiedniejsze do nich środki, lecz potrafi także najlepiej ich użyć do osiągnięcia zamierzonych celów.

Historia pedagogiki ilustruje licznymi przykładami pomysłowość praktyczną wybitnych talentów pedagogicznych. Święty Ignacy Loyola zaleca swym zakonnikom-nauczycielom po skończonej filozofii kilkuletnią praktykę nauczycielską. Święty Jan Chrzciciel de La Salle tworzy własny system wychowania i nauczania, w którym jako pierwszy w Europie posługuje się na szerszą skalę metodą zbiorowo-indywidualnego nauczania. Z kolei św. Jan Bosco, największy katolicki pedagog praktyczny, stworzył system metody prewencyjnej w wychowaniu, polegający szczególnie na badawczej i praktycznej obserwacji uczniów oraz zapobieganiu ich uchybieniom i występkom.

\section{Cecha postawy społecznej}

Istnieje związek wzajemny między jednostką a społecznością, gdyż świadczą sobie wzajemnie usługi niezbędne do obopólnego istnienia. ${ }^{57} \mathrm{~W}$ duchu solidaryzmu chrześcijańskiego zarysowuje się także postawa społeczna obydwu partnerów szkoły, nauczycieli i uczniów. Uczniowie zbliżają się do instytucji szkolnej, aby otrzymać dobra kulturalne i przez nie upodobnić się do swych przodków oraz przekazać je następnym pokoleniom. Tak więc postawa

56 Por. J. D a j c z a k, Katechetyka, s. 50.

$57 \mathrm{Z}$ jednej strony jednostka, jako mająca wiele potrzeb, nie mogłaby bez społeczności istnieć, wychować się, zdobyć wykształcenie i zbawić duszę w wieczności. Z drugiej zaś strony człowiek nie tylko umożliwia życie społeczności, ale też przyczynia się przez swe talenty i moralne cnoty do jej trwałości i rozwoju; por. tamże. 
nauczyciela wymaga, ${ }^{58}$ aby był on dobrym organizatorem, społecznikiem, a przede wszystkim człowiekiem o dużych walorach osobistych i z rozwiniętym poczuciem odpowiedzialności. Społeczna postawa nauczyciela wymaga od niego stosowania zasad sprawiedliwości w stosunku do uczniów, aby krzywda doznana przez ucznia nie wypaczała jego życia w kierunku aspołecznym. Człowiek jest istotą społeczną, ${ }^{59}$ żyje w społeczności i działa wspólnotowo.

Katecheta powinien przeżywać ducha wspólnoty, bo istotnie z powierzonymi sobie dziećmi czy młodzieżą tworzy pewnego rodzaju wspólnotę, społeczność, więź, rodzinę. ${ }^{60}$ Szkoła jest w swym założeniu przedłużeniem rodziny. Ten związek wzajemny nakłada więc na nauczyciela obowiązek współpracy z domem rodzinnym w dziele wychowania. W wychowaniu powinno się kłaść nacisk także na społeczną postawę nauczyciela-katechety na szczególną miłość ojczyzny, co podkreślali papież Pius XI, abp Bilczewski i Otto Willmann.

\section{Cecha powołania wewnętrznego do zawodu}

Podstawowa zasada wewnętrznego powołania oznacza, że w ramach swego powołania katecheta już od zarania swego życia nosi wrodzone tendencje i uzdolnienia do pracy naukowej, teoretycznej czy praktycznej, do pracy nauczycielskiej w szkole lub duszpasterskiej w parafii. ${ }^{61}$ Gdy jednak nauczycielowi brak niezbędnych zadatków uzdolnień pedagogicznych, gdy nie warunkują one nawet minimum sprawności nauczycielskich, wówczas katecheta nie ma

58 Nauczyciele i wychowawcy występują w swych funkcjach zawodowych jako zarządcy i szafarze wiedzy. Szkoła, jako istotny czynnik więzi społecznej w młodym wieku każdego pokolenia między nim samym a generacją dorosłych i pokoleń minionych, powinna wdrażać w umysły uczniów pietyzm dla czci i zasług tych, którzy odeszli, jak również dla żyjącego świata dorosłych; por. W. K u b i k, Jakie problemy zajmują obecnie dydaktyków w Polsce?, Collectanea Theologica 1/1973, s. 120.

59 Por. L. K a c z m a r e k, Postawy życiowe katechety, s. 193.

60 Por. tamíe.

${ }^{61}$ Por. J. D a j c z a k, Katechetyka, s. 358. 
wewnętrznego powołania do zawodu nauczycielskiego. ${ }^{62}$ Wprawdzie czynnik nadprzyrodzony, usilna praca nad sobą i szczęśliwy wpływ środowiska mogą uzupełnić wrodzone dyspozycje do nauczania dyspozycjami nabytymi, ale wtedy osobowość uczącego będzie sztuczna i nie tak wydajna, jak w przypadku aktualizowania dyspozycji wrodzonych.

Jak współczesny katecheta powinien organizować swoje powołanie, by trafić do dzisiejszego człowieka, zwłaszcza młodego, cierpiącego także na brak czasu i przerost informacji w szkole, TV, prasie itp.? W znalezieniu odpowiedzi na to pytanie niech nam pomoże kard. John Newman, który formułuje dwie zasady ${ }^{63}$ zapewniające właściwą skuteczność w nauczaniu katechetycznym: katecheta powinien podawać wiedzę religijną zawsze z uwzględnieniem poziomu umysłowego swoich uczniów; a ponadto katecheta musi stale łączyć formację czysto poznawczą z odpowiednią formacją osobowościową, jako celem i skutkiem nauczania.

\section{Cechy dydaktyczne osobowości katechetycznej}

Skuteczność przeżyciowej katechezy uzależniona jest od podłoża czysto ludzkiego osobowości katechety i znajomości dziecka na odcinkach jego faz rozwojowych, a także uwarunkowań związanych z jego środowiskiem społecznym i kulturowym. Katechetyka współczesna wymaga od chrześcijańskich nauczycieli wiedzy z dziedziny psychologii rozwojowej, jak również pewnych wiadomości z pedagogiki środowiskowej. ${ }^{64}$ Cechy pedagogiczne nie wystarczają nawet do przeciętnej umiejętności nauczania, dlatego nauczyciel powinien odznaczać się także cechami dydaktycznymi. Do tych zalet należą: żywość umysłu (inteligencja), łatwość kontaktu pedagogicznego (daru wykładania), zdolność wymowy w nauczaniu, dar intensywnego przeżywania wartości (głębszego nastroju uczuciowego).

\footnotetext{
62 Por. tamże.

63 Por. H. P i s z k a 1 s k i, O powołaniu katechety, Katechetyka 2/1978, s. 63.

${ }^{64}$ Por. J. D a j c z a k, Katechetyka, s. 293.
} 
Cecha żywości umysłu

Katecheta powinien przede wszystkim mieć cechę inteligencji, żywości umysłu, w wyniku której człowiek odznacza się różnorodnymi zainteresowaniami naukowymi, bogatą wyobraźnią, wierną pamięcią oraz skłonnością rozumu do rozeznawania przyczyn i przewidywania skutków. Na podłożu tych czynników struktury inteligencji człowiek nie poprzestaje już na osiągnięciach w granicach wykształcenia, lecz swoją wiedzę ciągle pomnaża i pogłębia. Zainteresowania nauką nie mogą być jednak przesadne ${ }^{65}$ Nauczyciel ma zazwyczaj uzdolnienia do określonego przedmiotu. Od tego też pochodzi ogólne zjawisko w świecie nauczycielskim, że wśród nich jedni mają zdolności do nauczania języków i przedmiotów humanistycznych, drudzy do nauk ścisłych, a jeszcze inni do nauk technicznych. ${ }^{66}$ Również wśród katechetów istnieją różne uzdolnienia dydaktyczne zależne od tych typów psychofizycznych i przeżyciowych. U jednych więc przeważa w metodzie styl myślowy filozoficzny, u innych katechetów pierwszeństwo ma indukcja, styl nauk humanistycznych, styl bezpośredni, obrazowy, pełen wzruszeń i przeżyć estetycznych, społecznych i religijno-moralnych.

Nauczyciel może doskonalić swój talent tylko w granicach swej osobowości osobniczej struktury i przedmiotów nauk, pozostających z nią w duchowym powinowactwie. Nauczyciel-katecheta uważa za styl, sens swojego życia, przekazywanie i utrwalenie wiedzy młodemu pokoleniu. Jest on zawsze gotów ze swą wiedzą i umiejętnością do usług dla dobra swych uczniów.

65 Należy unikać wszelkiego „wielowiedztwa”. Siły należy skupiać w kręgu zainteresowań tylko wybranymi przedmiotami, a nawet jednym przedmiotem, aby go móc tym lepiej zgłębić; por. tamże.

${ }^{66}$ Nawet w nauczaniu tego samego przedmiotu talent dydaktyczny poszczególnych nauczycieli wyraża się odrębnym stylem. Jedni więc uczą sucho, zwięźle i abstrakcyjnie, inni wkładają w lekcję całą swoją duszę pełną entuzjazmu, jeszcze inni uczą realnie, praktycznie i życiowo; por. tamże. 


\section{Cecha kontaktu pedagogicznego}

Dzięki umiejętności kontaktu pedagogicznego ${ }^{67}$ nauczyciel umie podawać naukę w odpowiedniej formie, zniżać się do sposobu myślenia dzieci i młodzieży oraz wczuwać się w ich potrzeby. Stosuje różnorodne formy katechetyczne, by katechezę ukształtować w sposób urozmaicony i wielostronny. Zawsze jednak powinien pamiętać o tym, że te formy są tylko po to, aby otworzyły katechumenów na Ducha Świętego. ${ }^{68}$

Cecha kontaktu pedagogicznego jest zwykle uwarunkowana cechami pedagogicznego autorytetu, taktu, miłości pedagogicznej i pomysłowości praktycznej. Odpowiadają jej cechy dydaktyczne żywości umysłu, wymowy i intensywnego przeżywania wartości. Prawdziwy katecheta kształci swój język pedagogiczny również w kontaktach z uczniami. W niższych klasach posługuje się językiem społecznym znanym dzieciom z codziennego życia. Chociaż używa go, nadając mu formę stylu literackiego, nie gwarowego, to jednak unika języka naukowego, posługującego się określeniami ścisłymi i abstrakcyjnymi.

\section{Cecha wymowy}

Problem znalezienia właściwego języka w przemawianiu do ucznia czy wychowanka znany jest dobrze nauczycielom i wychowawcom. Zna tę trudność również katecheta, w jego przypadku jest ona być może nawet większa. ${ }^{69}$ Oprócz dystansu, o jaki odsuwa nas od dzie-

${ }^{67}$ Ze względu na podłoże psychologiczne nazwano cechę pedagogiczną obcowania nauczyciela z uczniami kontaktem pedagogicznym albo kontaktowością; por. Katecheta 3/1961, s. 168.

68 Por. tamże.

${ }^{69} \mathrm{O}$ ile bowiem dom, rodzina i szkoła poszukują porozumienia z dzieckiem dla celów naturalnych, przyrodzonych, o tyle katecheta poszukuje form, które otworzyłyby duszę dziecka na sprawy największe i najważniejsze. Jego usiłowania w tym kierunku są nieraz daremne oraz ma wrażenie, jak gdyby mówił do dzieci językiem zupełnie obcym, i poczucie niemożności zainteresowania słuchaczy. Ma wówczas poczucie fiaska, które prowadzi nieraz do zniechęcenia: „Nie umiem znaleźć wspólnego języka z dziećmi”; por. Katecheta 1/1957, s. 36. 
cka naturalna granica wieku, dochodzi jeszcze trudność dodatkowa, specyficzna: płynie ona z samego przedmiotu, z mało nowoczesnych tradycji a wreszcie $\mathrm{z}$ braku opracowań, które są w takim przypadku pomocą. U podstaw właściwego języka katechetycznego leży przede wszystkim umiejętność obcowania z dziećmi i znajomość psychiki dzieci. $^{70}$ Trudności wynikających z braku tych umiejętności uniknie ten katecheta (katechetka), który jest jednocześnie wychowawcą. ${ }^{71}$

Ponadto umiejętność wymowy związana jest z kulturą języka. Chodzi o zdolność wyrażania się w języku ojczystym z czystością i jasnością, którą stawia się na pierwszym miejscu wśród cech kulturalnego człowieka. ${ }^{72}$ Powinien nauczyciel posługiwać się w swoim nauczaniu nie tylko mową, lecz także psychofizyczną strukturą, mimiką i gestami. Są to umiejętności ogólnoludzkie i zakorzenione głęboko w psychice. ${ }^{73}$ Ton głosu katechety, podobnie jak i cała jego postawa, ma świadczyć o jego życzliwości względem dzieci. Nauczyciel powinien zupełnie panować nad głosem. ${ }^{74}$ Dzieciom podoba się żywe słowo, zabarwione w niektórych momentach akcentem uczuciowym. Dobry nauczyciel starannie przygotowuje to, co ma powiedzieć, ale mówi żywo, a nie recytuje wyuczone formuły. Praca nad znalezieniem właściwego języka katechetycznego jest pracą trudną, w której uczący zdany jest w znacznej mierze na własne siły.

70 Por. tamíe.

71 Często jednak zdarza się, że katecheta ma przygotowanie tylko metodyczne, a pedagogiem nie jest, lub dopiero stara się nim być. Nie ma on kontaktu z dziećmi poza godziną religii. Nie czyta literatury dziecięcej, rzadko jest zorientowany w dziedzinach, które dzieciom imponują - w sporcie, kinie, szkolnych aktualnościach; rzadko zna dzieci od strony ich domowych warunków i trudności; por. tamże.

72 Por. J. D a j c z a k, Katechetyka, s. 365.

73 Nauczyciel-katecheta nie będzie mówcą, jeśli tylko formalnie pięknie będzie mówił. Dar wymowy wiąże się nie tylko ze słowem. Istnieje bowiem wymowność wyrazu twarzy, ruchów rąk, gestów, spojrzeń, wymowa modulowanego głosu, milczenia i symbolika całej postawy człowieka; por. tamże.

74 Głos ma być doniosły, musi wychodzić z pełnych płuc, ale nie może być krzykliwy. Mówić trzeba wyraźnie, powoli, poważnie, ale zarazem naturalnie, z zastosowaniem odpowiedniej modulacji głosu; por. tamże. 


\section{Cecha intensywnego przeżywania wartości}

Celem katechezy jest zdobywać serca słuchaczy dla Boga, dla życia w wierze w Chrystusa i we wspólnocie Kościoła. Sama wiedza zatem nie wystarcza. ${ }^{75}$ Katecheta winien być świadomy tego, że jest narzędziem Boga, który chce się udzielać przez katechetę. Katecheta musi być ponadto wierny temu, że jest wysłannikiem biskupa i reprezentuje Kościół, dlatego nie wykłada on osobistego poglądu, ale naukę Kościoła. Musi więc modlić się, aby Bóg użyczył mu właściwych słów i otworzył serca katechumenów. Przejęty swym przedmiotem powinien dążyć do wywołania w uczniach podobnych przeżyć, opartych na analogicznych poglądach i przeświadczeniach, zamiłowaniach, wzruszeniach, dążeniach i wspólnym działaniu w zakresie tej samej hierarchii wartości. ${ }^{76}$ Przeżycia religijno-moralne uczniów wzrastają szczególnie pod wpływem intensywnych przeżyć katechety, ${ }^{77}$ dlatego też katecheta powinien przygotowywać się do katechezy przez studium, przemyślenie, opracowanie i modlitwę. Winien przede wszystkim zdawać sobie sprawę z tego, do kogo będzie się zwracał. Zanim przemówi do katechumenów, musi sobie uświadomić: ${ }^{78}$ Czego zamierzam nauczyć? (treść); Dokąd chcę doprowadzić katechumenów? (cel); W jaki sposób chcę ukształtować katechezę?

75 Por. tamże, s. 167.

76 We współczesnym systemie pedagogicznym budowa lekcji szkolnej, szczególnie w przedmiotach humanistycznych, opiera się na przeżyciach. Do nich zaś należy przede wszystkim nauka religii, która jest wiedzą szczególnego rodzaju. Różne są rodzaje wiedzy. Jedna nie wpływa w ogóle na ukształtowanie życia jednostki. Druga wywiera na swym odbiorcy charakter swoisty, dodatni lub ujemny, żądając oddania się w jej służbę, jeśli uznał nad sobą jej panowanie. Trzecia wreszcie wiedza wywiera nie tylko ogromny wpływ na duchową postać człowieka, lecz ponadto jest dla niego niezbędna, gdyż sięga do podstaw jego bytu, rozstrzyga o jego losie w doczesność i wieczność, prowadzi go do Boga i wskazuje drogę do Niego. Tą ostatnią wiedzę zawiera właśnie nauka religii; por. tamże, s. 371.

77 Katecheta nie odniesie wielkiego pożytku z takich lekcji, do których najstaranniej się przygotowywał, ale nie odbywał przed nimi rozmyślań w przedmiocie ich treści; por. Katecheta 3/1961, s. 169.

78 Por. tamize. 
(droga). Intensywność przeżyć wartości zależy także od przedmiotu i wieku uczniów. ${ }^{79}$

$$
* * *
$$

Ksiądz Węglewicz jako pedagog zainteresował się szczególnie dwoma partnerami procesu nauczania i wychowania: nauczycielem-wychowawcą i jego uczniem-wychowankiem. Ukazał on wiele nowych cech katechety, które dotąd nie były dowartościowane przez katechetykę. Wielkim novum w dydaktyce ks. Węglewicza było odejście od tzw. tradycyjnego sposobu prowadzenia lekcji. Nowa metoda różni się tym, że nauczyciel podaje zadanie, a uczniowie przestają być biernymi słuchaczami i rozwiązują je w sposób zaangażowany. Nowością było też wprowadzenie przez ks. Węglewicza specjalnych czterech metod nauczania historii Kościoła: metoda budzenia zainteresowań, metoda tekstów historycznych, metoda analizy historycznej i metoda syntezy historycznej. Autor uważał, że katecheta powinien z nich korzystać na lekcji religii z pomocą osiągnięć wiedzy dydaktycznej. Winien ponadto stosować dydaktykę Jezusa Chrystusa, ${ }^{80}$ który uczył w najwyższym

79 Por. J. D a j c z a k, Katechetyka, s. 373. Postawa jednak nauczyciela w szkole podstawowej i średniej jest wychowawcza, gdyż nie kształci intelektualistów, lecz charaktery i osobowości, i to na lekcjach wszystkich przedmiotów, nie tylko humanistycznych, ale także przyrodniczych i technicznych. Oczywiście najwięcej przeżyć zakładają nauki humanistyczne; por. tamże.

${ }^{80}$ Dyrektorium Katechetyczne wprost powie o katechecie, że „występuje on w imieniu Kościoła jako świadek chrześcijańskiego orędzia, który służy innym, dzieląc się z nimi owocami własnej dojrzałej wiary, a wspólne poszukiwania mądrze kieruje do osiągnięcia zamierzonego celu”. DCG, nr 76. Zasadniczą podstawą świadczenia jest nakaz Chrystusa skierowany do uczniów po zmartwychwstaniu: „Będziecie mi świadkami w Jeruzalem i w całej Judei, i w Samarii i aż po końce ziemi” (Dz 1,8). Obowiązek świadczenia spoczywa na całym Kościele, lecz szczególnie dotyczy tych, którzy podejmują działalność duszpasterską. Konstytucja duszpasterska O Kościele w świecie współczesnym Gaudium et spes w nr 43 wyraźnie stwierdza: „Niech wszyscy duszpasterze pamiętają, że swoim codziennym zachowaniem i zapobiegliwością pokazują światu oblicze Kościoła, z którego ludzie wnoszą o mocy i prawdzie orędzia chrześcijańskiego". 
stopniu przystępnie, poglądowo, metodą naprowadzającą, praktycznie. Ksiądz Węglewicz przyczynił się do lepszego poznania uczniów, a tym samym do większej skuteczności katechezy. ${ }^{81}$ Cechy osobowości katechety przedstawione $\mathrm{w}$ tym opracowaniu mogą być pomocą dla nauczycieli religii w ich pięknej i odpowiedzialnej pracy. ${ }^{82}$

\section{ks. Wiestaw BACKOWSKI}

Słowa kluczowe: duszpasterstwo, katechetyka, metoda katechezy, nauczanie religii, osobowość katechety

Keywords: catechesis, a method of catechesis, pastoral care, personality catechist, religious instruction

\section{The personality of a Catechist on the basis of the indications of Father Mieczyslaw Węglewicz in the light of modern catechetics}

\section{Summary}

Father Mieczysław Węglewicz was an outstanding teacher and youth minister. He is a model catechist for modern catechesis. As a teacher and a didactic, Father Wegglewicz helps the students in the catechism class by finding the appropriate rules of conduct and way of life. His didactics allows the catechist to get to know the students better, thus providing a more effective catechesis.

81 Por. Z. B i e l a w s k i, Recenzja książki ks. M. Węglewicza: Studia psychologiczne nad młodzieżą klas wyższych, Miesięcznik Katechetyczno-Wychowawczy 1924, s. 29.

${ }^{82}$ Osoba katechety ma duży wpływ na młodzież przychodzącą na katechezę. Dla wielu z nich jest to okres kryzysu, niepokoju światopoglądowego czy nawet załamania w wierze. Nic więc dziwnego, że niejeden młody człowiek patrzy na religię i Kościół przez swojego katechetę i w nim przede wszystkim szuka potwierdzenia głoszonych prawd. Na tym tle nie budzi wątpliwości wniosek, że osobowość katechety jest dla katechizowanych pomocą w znalezieniu właściwych reguł postępowania i modelu życia. Ze szczególną ostrożnością zasada ta odnosi się do wychowania moralnego; por. S. J a c k o w s k i, Osobowość katechety młodzieży, s. 106-107. 